\title{
Şeker İkamesi Olarak Stevya Estraktı Kullanımının Keklerin Bazı Fiziksel ve Duyusal Özellikleri Üzerine Etkisi
}

\author{
Recep PALAMUTOĞLU*1, Cemal KASNAK ${ }^{1}$, Beyza MORAL ${ }^{2}$ \\ ${ }^{1}$ Afyon Kocatepe Üniversitesi, Afyon Sağlık Yüksekokulu, Beslenme ve Diyetetik Bölümü, Afyonkarahisar, Türkiye \\ ${ }^{2}$ Diyetisyen, Afyon Kocatepe Üniversitesi, Afyon Sağlık Yüksekokulu, Beslenme ve Diyetetik Bölümü, Afyonkarahisar, \\ Türkiye
}

Geliş Tarihi: 08.02 .2018

*Sorumlu Yazar: rpalamutoglu@aku.edu.tr Kabul Tarihi: 02.05.2018

Özet

Kekler tüm dünyada farklı formüllerle üretilebilen ve oldukça geniş bir tüketici kitlesi tarafından tüketilen ürünlerdir. Kek formülünde bulunan şekerin çeşitli fonksiyonel özellikleri vardır. Şeker enerji verdiğinden düşük kalorili ürün geliştirme amacı ile şeker ikameleri üzerine araştırmalar gerçekleştirilmektedir. Stevya özütü kullanımının bu tür ürünlerde meydana getireceği değişikliklere yönelik çalışmalarda artmaktadır. Bu çalışmada farklı oranlarda sıvı stevya özütü ilavesinin keklerin bazı kalite kriterlerine etkisi incelenmiştir. Şeker miktarları sırasıyla azaltılarak kontrol (şeker $140 \mathrm{~g}$ ), S1 (şeker $105 \mathrm{~g}$, stevya $3.93 \mathrm{~g}$ ), S2 (şeker $70 \mathrm{~g}$, stevya $7.87 \mathrm{~g}$ ) ve S3(şeker $35 \mathrm{~g}$, stevya $11.8 \mathrm{~g}$ ) olmak üzere 4 grup kek hazırlanmıştır. Örneklerde yapısal ve duyusal kalite analizleri gerçekleştirilmiştir. Duyusal analiz sonucunda belirlenen parametrelerin ortalaması olarak en yüksek puanı S1 grubu almıştır. Yapısal analizler sonucunda ön plana çıkan S2 grubunun kalori değeri kontrol grubuna göre \% 11 düşüş göstermiştir.

Anahtar Kelimeler: Kek, Stevya ekstraktı, Şeker, Kek kalitesi.

\section{The Effect of Using Stevia Extract as Sugar Replacer on Some Physical and Sensory Properties of Cakes}

\begin{abstract}
Cakes are a product that can be produced with different formulations all over the world and consumed by a very large consumer group. Sugar has various functional properties in the cake formula Researches on sugar substitutes are being carried out with the aim of developing low calorie products because sugar gives energy. There is also an increase in the number of studies on the effect of the use of Stevia extract in such products. In this study, the effect of addition of liquid stevia extract at different ratios on some quality criteria of cakes were examined. Four groups of cakes were prepared by decreasing the sugar content: control (sugar $140 \mathrm{~g}$ ), S1 (sugar $105 \mathrm{~g}$, stevia $3.93 \mathrm{~g}$ ), S2 (sugar $70 \mathrm{~g}$, stevia $7.87 \mathrm{~g}$ ) and S3 (sugar $35 \mathrm{~g}$, stevia $11.8 \mathrm{~g}$ ). Structural and sensory quality analyzes were carried out in the samples. As a result of the sensory analysis, the highest score was obtained as S1 as the average of the parameters determined. As a result of the structural analysis, the S2 group which was foreground showed 11\% decrease compared to the calorie control group.
\end{abstract}

Keywords: Cake, Stevia extract, Sugar, Cake quality. 


\section{Giriş}

Kek, hemen her ülkede üretilen, kalori değeri yüksek, göz ve damak zevkine hitap eden çeşitlilikte, farklı formüllerde ve şekillerde üretilen bir gıda ürünüdür (Dizlek ve ark., 2008; Dizlek ve Özer, 2018). Gıda endüstrisinde firıncılık ürünlerinde şeker ikamesi kullanımına yönelik ilgi artmaktadır ve bu sayede enerjisi ve şeker içeriği azaltılmış ürünler elde edilebilmektedir (Gao ve ark. 2016). Türk Gıda Kodeksine göre, enerji ya da kalorisi; yani yă̆, karbonhidrat ve şeker oranları \% 25 azaltılan ürünler “düşük kalorili” sınıfına girmektedir. Kek yapımında şekerin birçok fonksiyonu söz konusudur; ürüne hoşa giden tatlı bir lezzet vermesi, nem muhafazasını kontrol etmesi, hava kabarcıklarını dengelemesi, bu suretle ürünün gözenek yapısını ve tekstürünü geliştirmesi, pişirme sırasında nişastanın jelleşmesini sınırlaması, kütle oluşturması ve dokunun düzgün olmasını sağlamasıdır (Dizlek, 2003 ve 2013; Nip, 2014).

S. rebaudiana özütündeki temel bileşen olan steviosid, kalorisiz ve çok yüksek tatlandırıcı özelliğe sahip olup tatlandırıcı amaçlı az miktarlarda kullanımı yeterlidir. Özellikle obez kişilerde ve diyabetik hastalarda şeker yerine kullanılabilecek iyi bir alternatif olduğu düşünülen stevyanın tatlandırıcı olarak ticari preparatlarının piyasaya sürülmesi ve gıda maddelerinin içerisinde tatlandırıcı olarak kullanılmasıyla tüketimi gün geçtikçe artmaktadır (Chatsudthipong ve Muanprasat, 2009; Gürleyik, 2010; Giritlioğlu ve Dizlek, 2018).

Stevya'nın enerji değeri kuru madde esasına göre 2.7 kcal/g olarak ölçülmüştür, fakat ekstrakte edilmiş hali kalorisiz olarak kabul edilmektedir. Bunun yanı sıra, asesülfam K'nın enerji degeri 0, aspartamın 4 kcal/g, sakarinin 0 kcal/g ve sukralozun 0 kcal/g'dır. Sakaroz (şeker) tüketiminin günlük diyetteki kalori miktarına katkısı oldukça yüksektir ve kilo artışına neden olur. Bu nedenle günlük diyette kalorisiz bir tatlandırıcı olan stevyanın kullanımı, alınan kalori miktarının azalmasını sağlamaktadır (Karaca, 2010).

Stevya'dan elde edilen tatlandırıcılar; sakkaroza göre 250-300 kat daha fazla tatlı olması, 1s1 ve pH stabilitesinin yüksek olması, pişirme ve fırın stabilitesinin olması, alkol içerisinde çözünmesi, ağızda metalimsi tadın olmaması gibi özelliklerinin yanında en büyük özelliği doğal yollarla elde edilmesidir (İnanç ve Çınar, 2009; Aswinve ark., 2015; Giritlioğlu ve Dizlek, 2018). Ayrıca esmerleşmeye ve karamelizasyona neden olmadığı belirlenmiştir (JECFA, 2007). Bu çalışma ticari olarak piyasada satılan sıvı stevya ürününün keklerde şeker ikamesi olarak kullanımının bazı kalite karakteristikleri ve duyusal özellikleri üzerine etkilerinin araştırılmasını amaçlanmaktadır. 


\section{Materyal ve Metot}

\subsection{Materyal}

Kek yapımında kullanılan malzemeler; buğday unu (Kül miktarı: \%0,65, Protein miktarı: \%10,5 Sinangil (çok amaçlı buğday unu)), toz şeker (Doğuş), ayçiçek yağı (Komili), yağsız süt tozu (Pınar), kabartma tozu (Dr.Oetker), taze günlük yumurta (İşlek, A sınıfi), su (Damla) ve tuz piyasadan temin edilmiştir. Çalışmada kullanılan sıvı stevya (Stevia Ekstrakt (Stevia rebaudian ), Antioksidan (Potasyum Sitrat), Koruyucu (Potasyum Sorbat), Asitlik düzenleyici (Sitrik Asit), Deiyonize Su Optinaturel İlaç Gıda Med. San. Tic. Ltd. Şti Firması'ndan (Naturpy, Ankara) temin edilmiştir.

\subsection{Kek hamurunun hazırlanması ve pişirilmesi}

Araştırmada kullanılacak kek formülünün belirlenmesi için ön denemeler yapılmış ve böylece en uygun kek formülü belirlenmiştir. Ayrıca uygun pişme sıcaklığg ve süresi ön denemeler neticesinde belirlenmiştir (sonuçlar gösterilmemiştir). Kontrol (şeker 140 g), S1 (şeker 105 g, stevya 3.93 g ), S2 (şeker $70 \mathrm{~g}$, stevya $7.87 \mathrm{~g}$ ) ve S3(şeker $35 \mathrm{~g}$, stevya $11.8 \mathrm{~g}$ ) olmak üzere 4 farklı formüle sahip kek numunesi hazırlanmıştır (Çizelge 1.).

Kullanılan malzemeler 45 d öncesinden oda sıcaklığına bırakılmıştır. İlk olarak un, kabartma tozu ve tuz ayrı bir kapta homojen bir karışım oluşturacak şekilde karıştırılmıştır. Daha sonra hamurun hazırlanacağı kaba yumurta ve şeker ilave edilerek mikserle düşük hızda (2. devir) $75 \mathrm{~s}$, orta hızda (4. devir) $70 \mathrm{~s}$ boyunca çırpılmıştır (Vestel /VCook2000). Bu çırpma işleminin ardından sıvı malzemeler, sulandırılmış süt tozu ve yağ eklenip $60 \mathrm{~s}$ daha karıştırılmıştır. Daha önceden hazırlanan toz karışım ilave edilerek $120 \mathrm{~s}$ bütün malzemeler karıştırıldıktan sonra elde edilen hamur kağıt muffin kalıplarına (Korkmaz, taban çapı $5 \mathrm{~cm} \pm 0$,2) ağırlıkları $35 \mathrm{~g} \pm 5$ olacak şekilde tartılmış ve hazırlanmıştır.

Elde edilen hamurlar daha önceden $175^{\circ} \mathrm{C}^{\prime}$ ye ayarlanmış olan firında (Arçelik /9620 Mı) 20 d pişirilmiştir. Pişme süresi sonunda kekler fırından çıkarılarak oda sıcaklığında 1 saat soğumaya bırakılmıştır (Dizlek, 2015). Daha sonra analiz edilinceye kadar ambalajlanarak oda sıcaklığında muhafaza edilmiştir. Analizler 2 tekerrürlü olarak yürütülmüştür. Buna göre gerçekleştirilen analizler aşağıda verilmiştir. 
Çizelge 1. Araştırmada Üretilen kek örneklerine ait formüller.

\begin{tabular}{lcccc}
\hline Bileşenler $(\mathrm{g})$ & Kontrol & S1 & S2 & S3 \\
\hline Buğday Unu & 230,6 & 230,6 & 230,6 & 230,6 \\
Yağ & 115,2 & 115,2 & 115,2 & 115,2 \\
Su & 115,2 & 115,2 & 115,2 & 115,2 \\
Yumurta & 69,2 & 69,2 & 69,2 & 69,2 \\
Yağsız Süt tozu & 17,4 & 17,4 & 17,4 & 17,4 \\
Kabartma Tozu & 11,6 & 11,6 & 11,6 & 11,6 \\
Tuz & 1,4 & 1,4 & 1,4 & 1,4 \\
Şeker & 140 & 105 & 70 & 35 \\
Stevyaekstaktı & - & 3,93 & 7,87 & 11,80 \\
\hline
\end{tabular}

\subsection{Analizler}

Araştırmada üretilen keklerin hacimleri AACCI Metot 10.05.01 (AACCI, 2000)'e göre kolza tohumları ile yer değiştirme prensibinden yararlanılarak belirlenmiştir. Hacim değeri firından çıkarılıp 1 saat dinlendirildikten sonra tartılıp belirlenen kek ağırlığına bölünerek örneklerin özgül hacimleri hesaplanmıştır (Dizlek ve Altan, 2013).

AACCI Metot 10-91.01 (AACCI, 2000)'e göre soğutma işlemi bittikten sonra kekler dikey olarak merkezlerinden dikkatlice kesilmiş, milimetrik kağıt ile hazırlanmış olan şablonun üzerine kesilmiş yüzeyleri gelecek şekilde yerleştirilmiş ve metotta belirtilen AA', BB', CC', DD', EE', AE, A'E' yükseklikleri milimetrik şablondan okunmuştur. Daha sonra bu değerler kullanılarak indeksler hesaplanmıştır (Dizlek ve Altan, 2013). Metotta belirtilen ölçüm şablonu $20 \mathrm{~cm}$ uzunluğunda olup yapmış olduğumuz çalışmaya modifiye edilerek 10 cm'ye düşürülmüş, B ve D noktaları merkezin sağında ve solunda merkeze $2 \mathrm{~cm}$ uzaklıkta, A ve E noktaları ise yine merkezin sağında ve solunda 5' er cm uzaklıkta yer almıştır. Ölçüm şablonu keklerin hacimle ilgili olan bazı yapısal özellikleri hakkında fikir vermektedir. Söz konusu özellikler; hacim, simetri ve tekdüzelik indeksleri ile büzülme değeridir.

Hacim indeksi (mm): BB'+ CC'+ DD'

Simetri indeksi (mm): 2 x CC'- BB'- DD'

Keklerin fırından çıkarıldıktan 1 saat sonra ağırlıkları tartılmıştır. Kek ağırlığının başlangıçtaki hamur ağırlığına bölünüp 100 ile çarpılmasıyla kek verimi, elde edilen bu değerin 100' den çıkarılmasıyla da kek örneklerinin pişme kaybı hesaplanmıştır (Dizlek ve Altan, 2013).

Hamur örnekleri ve kek numunelerinin pH derecesi ölçülmüştür (Dizlek, 2003).

Keklerin nem içeriği Ohaus marka MB45 modeli nem tayin cihazı ile Dizlek ve Özer (2016)E göre ölçülmüştür. 
Kekin örneklerinin su aktivitesi dijital su aktivite cihazı (NovasinaLabTouch-aw/İsviçre) yardımıyla ölçülmüştür (Hojjatoleslami ve Azizi, 2015).

Kek numunelerinin kabuk ve kesit yüzeylerirenkleri X-Rite renk ölçme cihazı (Ci6X) ile Hunter renk ölçme sisteminde renk $\left(\mathrm{L}^{*}, \mathrm{a}^{*}, \mathrm{~b}^{*}\right)$ değerleri ölçülerek yapılmıştır (Hojjatoleslami ve Azizi, 2015).

Elde dilen $\mathrm{a}^{*}$ ve $\mathrm{b}^{*}$ değerleriyle hesaplanan $\mathrm{C}^{*}$ değeri "Croma" renk doygunluğunu ifade etmekte,renk açısını (ton açısı) ifade eden h değeri de tespit edilmiştir.

Üretilen ürünlerin tümü BEBİS (Beslenme Bilgi Sistemleri) kullanılarak besin değeri açısından analiz edilerek değerlendirilmiş ve enerji değeri hesaplanmıştır. Besin değeri analizi yapılması için kullanılan malzemelerin ambalaj beyanlarındaki enerji ve makro besin ögeleri BEBİS 7.2 programına tanıtılmış ürünlerin tarifleri girilerek besin değeri analizi yapılmıştır.

Duyusal analiz ürünün kalitesi hakkında tüketicinin beğenisini ve isteklerini yansıttığı için oldukça önemlidir.

Üretilen kek örnekleri arasındaki farkı ve depolama süresinin etkilerini belirlemek amaciyla tek yönlü varyans analizi (One-wayAnova) uygulanmıştır. Bu amaçla IBM SPSS Statistics Versiyon 18.0 (SPSS Inc. Chicago, Illinois) istatistik analiz paket programı kullanılmıştır. Varyans analizi sonucunda önemli olan veriler Tukey çoklu karşılaştırma testine göre $\mathrm{p}<0.5$ düzeyinde test edilmiştir.

\section{Bulgular ve Tartışma}

\subsection{Kek Örneklerine Ait pH, Nem ve Su Aktivitesi Değerleri}

Farklı seviyelerde stevya eklenmiş kek örneklerinin $\mathrm{pH}$, nem ve su aktivitesi değerlerine ait ortalamalar Çizelge 2'de verilmiştir. Buna göre kek hamurlarının $\mathrm{pH}$ değerleri arasında istatistiki olarak fark çıkmazken ( $>0.05$ ), kek örneklerinin $\mathrm{pH}$ değerlerinde istatistiki olarak fark önemli $(\mathrm{p}<0.05)$ bulunmuştur. En yüksek pH değeri \% 75 stevya eklenmiş kek örneklerinde görülmüşken, en düşük değeri kontrol grubu almıştır.

Çizelge 2. Farklı seviyelerde eklenmiş stevya ile şeker içeriğinin azaltılması amaçlanan kek örneklerinin ve kek hamurlarının pH değerlerine ait ortalamalarının Tukey Çoklu Karşılaştırma Test Sonuçları

\begin{tabular}{clccc}
\hline & Hamur pH's1 & Kek pH's1 $^{* *}$ & Nem $^{* *}$ & Su Aktivitesi* $^{*}$ \\
\hline Kontrol & $6.92 \pm 0.02$ & $7.55^{\mathrm{d}} \pm 0.01$ & $14.73^{\mathrm{c}} \pm 0.19$ & $0.719^{\mathrm{b}} \pm 0.04$ \\
S1 & $6.88 \pm 0.03$ & $7.71^{\mathrm{b}} \pm 0.01$ & $13.71^{\mathrm{c}} \pm 0.61$ & $0.800^{\mathrm{a}, \mathrm{b}} \pm 0.07$ \\
S2 & $6.88 \pm 0.03$ & $7.65^{\mathrm{c}} \pm 0.02$ & $18.51^{\mathrm{b}} \pm 0.86$ & $0.808^{\mathrm{a}, \mathrm{b}} \pm 0.07$ \\
S3 & $6.89 \pm 0.04$ & $7.80^{\mathrm{a}} \pm 0.01$ & $25.59^{\mathrm{a}} \pm 0.06$ & $0.861^{\mathrm{a}, \mathrm{b}} \pm 0.07$ \\
\hline
\end{tabular}

Her bir sütunda farklı harflerle gösterilen değerler arasında istatistiki olarak fark vardır $(* \mathrm{p}<0.05$, ** $\mathrm{p}<0.01)$. 
Çizelge 2 incelendiğinde kek örneklerinin nem içeriği değerleri arasında istatistiki olarak fark çok önemli $(\mathrm{p}<0.01)$ bulunmuşken, su aktivitesi değerleri arasında fark önemli $(\mathrm{p}<0.05)$ bulunmuştur. En fazla nem içeriği S3 örneklerinde görülmüş, en düşük değeri ise S1 grup almıştır. Örneklerin stevya içeriği arttıkça su aktivitesi değerleri de artmış en yüksek değeri \% 75 stevya içeren grup almıştır. Vatankhah ve ark. (2015) yaptıkları çalışmada şeker ikamesi olarak steviozit ilavesinin, bisküvilerin nem miktarlarını ve su aktivitesi değerlerini ikame oranın artışına bağlı olarak istatistiki açıdan önemli oranda artırdığını bildirmişleridir.

\subsection{Kek Örneklerine Ait Pişme Kaybı, Kek Verimi ve Spesifik Hacim Değerleri}

Farklı seviyelerde eklenmiş stevya ile şeker içeriğinin azaltılması amaçlanan kek örneklerinin pişme kaybı, kek verimi ve spesifik hacim değerlerine ait ortalamalar çizelgelerde verilmiştir.

Çizelge 3 incelendiğinde pişme kaybı ve kek verimi değerleri arasında istatistiki olarak fark çok önemli $(\mathrm{p}<0.01)$ bulunmuştur. Pişme kaybının en az, kek veriminin ise en yüksek görüldüğü grup S1 örnekleridir. Pişme kaybının en fazla, verimin en düşük bulunduğu grup ise S3 kek örnekleridir. Keklere sıvı stevya ilavesinin artışına bağlı olarak pişirme işlemi ile buharlaşma nedeni ile nem kaybı olduğu söylenebilir. $\mathrm{Bu}$ sebeple örneklerin pişme kayıpları eklenen stevya miktarı artışıyla artmaktadir.

Hacim, özgül hacim, hacim indeksi ve simetri indeksi değerlerinin ortalamaları incelendiğinde örnekler arasında istatistiki olarak fark bulunmamıştır $(\mathrm{p}>0.05)$.

Çizelge 3. Faklı seviyelerde eklenmiş stevya ile şeker içeriğinin azaltılması amaçlanan kek örneklerinin pişme kaybı, kek verimi ve spesifik hacim değerlerine ait ortalamalarının Tukey Çoklu Karşılaştırma Test Sonuçları

\begin{tabular}{ccccccc}
\hline & $\begin{array}{c}\text { Pişme } \\
\text { Kaybı }^{* *}\end{array}$ & Kek Verimi & $\begin{array}{c}\text { Spesifik } \\
\text { Hacim } \\
\left(\mathrm{cm}^{3} / \mathrm{g}\right)\end{array}$ & $\begin{array}{c}\text { Hacim } \\
\text { indeksi }\end{array}$ & Hacim $\left(\mathrm{cm}^{3}\right)$ & $\begin{array}{c}\text { Simetri } \\
\text { indeksi }\end{array}$ \\
\hline Kontrol & $14.78^{\mathrm{b}, \mathrm{c} \pm 0.69}$ & $85.22^{\mathrm{a}, \mathrm{b}} \pm 0.69$ & $2.37 \pm 0.45$ & $76.20 \pm 3.25$ & $211.95 \pm 4.74$ & $7.80 \pm 1.41$ \\
S1 & $13.81^{\mathrm{c}} \pm 0.53$ & $86.18^{\mathrm{a}} \pm 0.53$ & $2.53 \pm 0.25$ & $71.51 \pm 1.00$ & $204.35 \pm 3.75$ & $2.15 \pm 1.20$ \\
S2 & $15.97^{\mathrm{a}, \mathrm{b}} \pm 0.27$ & $84.02^{\mathrm{b}, \mathrm{c} \pm 0.27}$ & $2.96 \pm 0.07$ & $69.90 \pm 0.57$ & $192.85 \pm 3.32$ & $9.30 \pm 2.26$ \\
& & & & & & \\
S3 & $16.92^{\mathrm{a}} \pm 1.10$ & $83.07^{\mathrm{c}} \pm 1.10$ & $2.41 \pm 0.35$ & $72.50 \pm 2.97$ & $198.05 \pm 7.28$ & $7.45 \pm 2.33$ \\
\hline Her bir sütunda farkl1 harflerle gösterilen değerler arasinda istatistiki olarak fark vardır $(* \mathrm{p}<0.05, * * \mathrm{p}<0.01)$.
\end{tabular}


Kek örneklerinde şeker ikamesi olarak sıvı stevya kullanılması keklerin pişirilmesi sırasında sıcaklığa bağlı olarak buharlaşma nedeni ikame oranının artışına bağlı olarak pişme kaybında artışa buna bağlı olarak ta kek veriminde azalmaya neden olmuştur.

Hacim indeksi kek örneklerinin hacmi hakkında fikir vermektedir (Dizlek ve Altan, 2015). Simetri indeksi keklerin üst kısımlarının yüzey profillerini belirlemek için kullanılmaktadır. Simetri indeksinin pozitif değere sahip olması kek üst yüzeyinin bombeli olduğunu, negatif değer alması ise kekin çöktüğünü göstermektedir (Dizlek ve Özer, 2018). Analiz sonuçlarına göre simetri indeksi değerlerinin pozitif olması tüketici açısından kek görünümünün olumlu olmasını sağlamaktadır.

Hacim değerlerinde en büyük değeri kontrol grubu en düşük değeri ise S2 grubu almıştır. Hemada ve ark. (2016) yaptıkları çalışmada kek örneklerinin spesifik hacim değerlerini 2.01 ila 2.6 arasında tespit etmişlerdir. Aynı şekilde Zabihollahi (2014) düşük kalorili kek üretimi üzerine yaptığı çalışmada \%50 şeker azaltılmış örneklerle kontrol örneklerinin hacim ve özgül hacim değerleri arasında fark olmadığını \%100'lük ikame uygulanan örneklerde ise önemli bir düşüşün meydana geldiğini bildirmiştir. Bu durumunda formüldeki şekerin kullanılmaması sonucu kekin hava tutma kapasitesinin azalacağını, böylelikle hacim ve spesifik hacimlerde azalma meydana gelebileceğini ifade etmiştir.

Vatankhah ve ark. (2015) \%100 oranında stevyozit ikamesinin bisküvilerin hacimlerinde, spesifik hacimlerinde önemli oranda azalma meydana getirdiğini bildirmişlerdir.

\subsection{Kek Örneklerine Ait Renk Sonuçları}

Çizelge 4. Farklı seviyelerde eklenmiş stevya ile şeker içeriğinin azaltılması amaçlanan kek örneklerinin kabuk rengi değerlerine ait ortalamaların Tukey çoklu karşılaştırma test

\begin{tabular}{cccccc}
\hline & $L^{*}$ & $\boldsymbol{a}^{*}$ & $\boldsymbol{b}^{*}$ & $\boldsymbol{C}$ & $\boldsymbol{h}$ \\
\hline Kontrol & $46.92^{\mathrm{b}} \pm 0.52$ & $18.31^{\mathrm{a}} \pm 0.54$ & $34.46^{\mathrm{b}, \mathrm{c}} \pm 1.50$ & $39.02^{\mathrm{b}} \pm 1.07$ & $61.98^{\mathrm{b}} \pm 1.74$ \\
S1 & $64.16^{\mathrm{a}} \pm 0.96$ & $9.75^{\mathrm{b}} \pm 0.61$ & $38.79^{\mathrm{a}, \mathrm{b}} \pm 0.52$ & $40.00^{\mathrm{b}} \pm 0.67$ & $75.89^{\mathrm{a}} \pm 0.66$ \\
S2 & $48.16^{\mathrm{b}} \pm 0.34$ & $18.67^{\mathrm{a}} \pm 0.09$ & $32.17^{\mathrm{c}} \pm 0.35$ & $37.19^{\mathrm{b}} \pm 0.35$ & $59.86^{\mathrm{b}} \pm 0.13$ \\
S3 & $54.49^{\mathrm{b}} \pm 3.56$ & $17.93^{\mathrm{a}} \pm 1.87$ & $40.54^{\mathrm{a}} \pm 1.70$ & $44.36^{\mathrm{a}} \pm 0.79$ & $66.10^{\mathrm{b}} \pm 3.11$
\end{tabular}

Her bir sütunda farklı harflerle gösterilen değerler arasında istatistiki olarak fark vardır $(\mathrm{p}<0.05)$.

Hemada ve ark. (2016) yaptıkları çalışmada steviosid ekstraktı ilaveli kek örneklerinin L*, a*, $\mathrm{b}^{*}$ ve hue değerlerini sirasıyla ortalama 46.33-56.51, 2.64-5.91, 2.1-16.03 ve 25.50-72.34 arasında tespit etmişılerdir. İstatistiki olarak fark olmadığını bildirmişlerdir. Çalışmamızda ise L değerleri açısından yaklaşık değerler tespit edilmiştir en parlak grup S1 örnekleri olmuştur ve istatistiki olarak fark önemli olduğu belirlenmiştir. A ve b değerleri ise daha yüksek değerlere sahip olup S1 örnekleri 
en kırmızı, S3 örneklerinin en sarı olduğu ama S1 örnekleri ile farkın önemli olmadığı belirlenmiştir. Vatankhah ve ark. (2015) en yüksek L* $a^{*} b^{*}$ değerlerini sirasılla \%100, \%0, \%50-100 steviyozit ikameli örneklerin aldığını ifade etmişlerdir. Zabihollahi (2014) keklerin kabuk L* değerinin şeker ikame edilmeyen örneklerde en düşük buna rağmen a* değerinin en yüksek olduğunu b* değerleri açısından farklılık bulunmadı̆̆ını bildirmiştir.

Çizelge 5. Faklı seviylerde eklenmiş stevya ile şeker içeriğinin azaltılması amaçlanan kek örneklerinin kesit rengi değerlerine ait ortalamaların Tukey çoklu karşılaştırma test sonuçları

\begin{tabular}{cccccc}
\hline & $L^{*}$ & $\boldsymbol{a}^{*}$ & $\boldsymbol{b}^{*}$ & $\boldsymbol{C}$ & $\boldsymbol{h}$ \\
\hline Kontrol & $64.97 \pm 0.39$ & $1.12 \pm 0.35$ & $22.36 \pm 1.14$ & $22.39 \pm 1.16$ & $87.13 \pm 0.74$ \\
S1 & $65.16 \pm 3.12$ & $0.32 \pm 0.32$ & $19.89 \pm 0.26$ & $19,89 \pm 0.26$ & $89.05 \pm 0.93$ \\
S2 & $70.85 \pm 3.33$ & $0.66 \pm 0.56$ & $22.15 \pm 0.78$ & $22.16 \pm 0.80$ & $88.30 \pm 1.39$ \\
S3 & $65.67 \pm 1.11$ & $0.63 \pm 0.30$ & $22.86 \pm 1.57$ & $22.86 \pm 1.58$ & $88.44 \pm 0.64$ \\
\hline
\end{tabular}

Kek örneklerinin kesit yüzey renk değerleri arasında istatistiki olarak farkın önemli olmadığ1 belirlenmiştir. Zabihollahi (2014) şeker içeriği azaltılmış keklerin kesit yüzey L* a* değerleri açısından farkların önemli olduğunu, b* değeri açısından ise önemli fark olmadığını bildirmiştir.

Şekil 1'de kek örneklerinin kabuk görüntüleri, Şekil 2'de kek örneklerinin kesit görüntüleri verilmiştir.

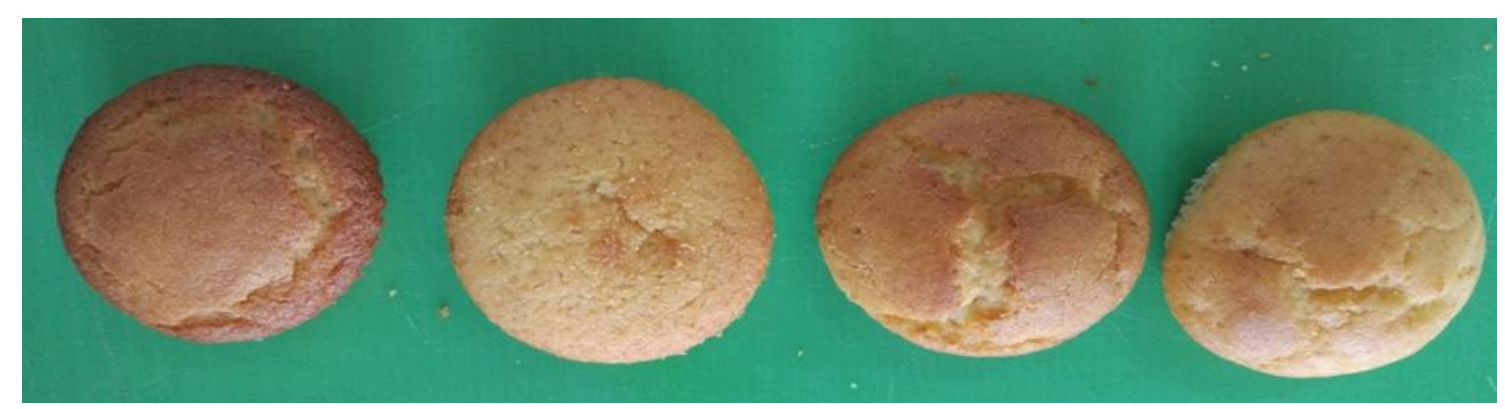

Şekil 1. Kek Örnekleri Kabuk Görüntüleri (soldan sağa kontrol, S1, S2, S3)

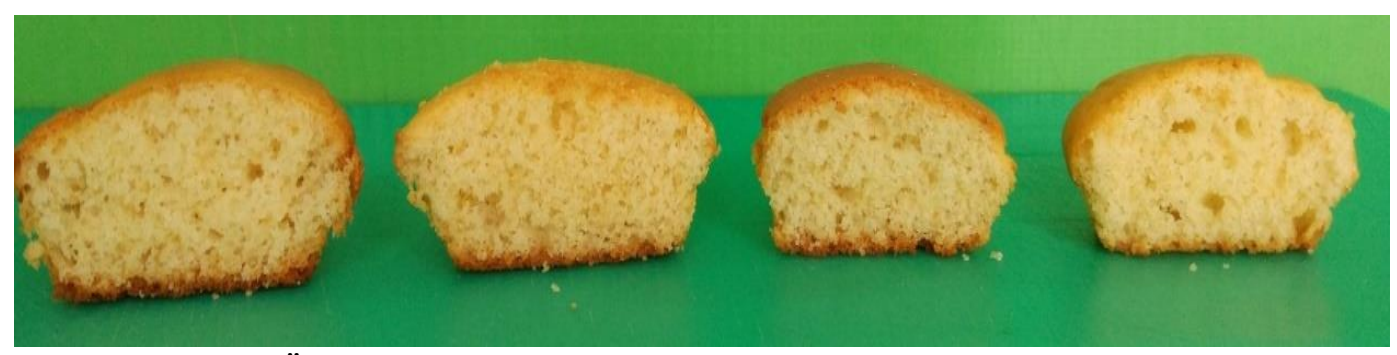

Şekil 2. Kek Örnekleri Kesit Yüzey Görüntüleri (soldan sağa kontrol, S1, S2, S3) 


\subsection{Duyusal Analiz Sonuçları}

Panelistlerden kek örneklerinin anlatılan standarda göre kontrol grubu ve $\% 25$ stevya, \%50 stevya, \%75 stevya içeriğine sahip grupların değerlendirmeleri istenmiştir. Kullanılan puanlama testi ile kalite farklılıkları ve bu farklılığın dereceleri tespit edilmiştir. Değerlendirme on bir üyeden oluşmuş ve 9 bölmeli hedonik tip skala kullanarak belirtilmiştir (Yıldız, 2002). Panel üyelerine kekler numaralandırılmış numune kapları içerisinde değerlendirme formu ile birlikte sunulmuştur. Öncelikle kontrol grubunun kekin duyusal değeri belirlenmiş daha sonra diğer keklerin özelliklerinin bu değerlendirmeye göre hangi konumda olduğunun belirtilmesi istenmiştir. Duyusal analizde panelistlerden kabuk rengi, kabuk kalınlığı, kek iç rengi, gözenek durumu, esneklik, nemlilik ve yapışkanlık, tat aroma, yutulabilirlik, ağızda bıraktığg his ve genel tekstür açısından değerlendirmeleri istenmiş ve Çizelge 6'daki ortalamalar elde edilmiştir.

Çizelge 6. Stevya ilaveli keklerin duyusal analiz sonuçları

\begin{tabular}{lcccccccc}
\hline & Kabuk Rengi & $\begin{array}{c}\text { Kabuk } \\
\text { Kalınlığı }\end{array}$ & $\begin{array}{c}\text { Gözenek } \\
\text { Durumu }\end{array}$ & $\begin{array}{c}\text { Nemlilik ve } \\
\text { Yapışkanlık }\end{array}$ & Tat Aroma & Yutulabilirlik & $\begin{array}{c}\text { Ağızda } \\
\text { Bıraktı̆̆ His }\end{array}$ & $\begin{array}{c}\text { Genel kabul } \\
\text { edilebilirlik }\end{array}$ \\
\hline Kontrol & $4.55^{\mathrm{b}} \pm 1.63$ & $5.45^{\mathrm{c}} \pm 1.57$ & $6.00 \pm 1.48$ & $3.73^{\mathrm{b}} \pm 1.55$ & $5.45 \pm 1.44$ & $5.27^{\mathrm{b}} \pm 1.90$ & $6.00^{\mathrm{b}} \pm 1.09$ & $6.00^{\mathrm{b}} \pm 1.84$ \\
$\mathrm{~S} 1$ & $7.45^{\mathrm{a}} \pm 1.81$ & $7.91^{\mathrm{a}} \pm 0.70$ & $7.36 \pm 1.50$ & $5.91^{\mathrm{a}} \pm 1.81$ & $7.27 \pm 1.49$ & $7.36^{\mathrm{a}} \pm 1.12$ & $7.45^{\mathrm{a}} \pm 1.44$ & $7.73^{\mathrm{a}} \pm 0.90$ \\
$\mathrm{~S} 2$ & $6.09^{\mathrm{a}, \mathrm{b}} \pm 1.64$ & $5.73^{\mathrm{b}, \mathrm{c}} \pm 2.28$ & $6.09 \pm 2.12$ & $4.36^{\mathrm{a}, \mathrm{b}} \pm 1.86$ & $5.82 \pm 1.72$ & $5.91^{\mathrm{a}, \mathrm{b}} \pm 1.92$ & $6.18^{\mathrm{a}, \mathrm{b}} \pm 1.40$ & $6.27^{\mathrm{a}, \mathrm{b}} \pm 1.74$ \\
$\mathrm{S3}$ & $7.36^{\mathrm{a}} \pm 1.63$ & $7.27^{\mathrm{a}, \mathrm{b}} \pm 1.10$ & $7.27 \pm 1.01$ & $6.27^{\mathrm{a}} \pm 1.79$ & $6.91 \pm 1.81$ & $6.82^{\mathrm{a}, \mathrm{b}} \pm 1.40$ & $7.18^{\mathrm{a}, \mathrm{b}} \pm 1.08$ & $7.55^{\mathrm{a}, \mathrm{b}} \pm 0.69$
\end{tabular}

Her bir sütunda farklı harflerle gösterilen değerler arasında istatistiki olarak fark vardır ( $<<0.05)$.

Değerler incelendiğinde kabuk rengi, kabuk kalınlığı, nemlilik ve yapışkanlık, genel tekstür, tat aroma, yutulabilirlik ve ağızda bıraktığı his açısından istatistiki olarak fark önemli $(\mathrm{p}<0.05)$ bulunmuştur.

Nemlilik ve yapışkanlık kriteri dışındaki diğer değerlendirmeler de \% 25 stevya içeren kek örnekleri en yüksek ortalama puanı almışken, nemlilik ve yapışkanlıkta \% 75 stevya içeren grup beğeni kazanmıştır.

Vatankhah ve ark. (2015) \%50 oranında stevyozit ikameli bisküvilerin renk haricinde tat, lezetaroma, tekstür-çiğnenebilirlik, ve genel kabul edilebilirlik açısından kontrol grubu ile aralarında önemli farklılığın olmadığını bildirmişlerdir.

Genel kabul açısından \% 25 stevya içeren grup en beğenilen grup olmuştur ve ardından \%75 stevya içeren kek örnekleri beğenilmiştir.

Khalil ve ark. (2015) \%50’ye kadar şekerin steviyozitle ikame edilmesinin keklerin tüm duyusal parametreleri arasında herhangi bir farklılığa yol açmadığını ifade etmişlerdir. 


\subsection{Kek Örneklerine Ait Enerji Değerleri}

Farklı seviyelerde eklenmiş stevya ile şeker içeriğinin azaltılması amaçlanan kek örneklerinin enerji değerleri Çizelge 7'de verilmiştir. Kek örneklerinde şeker içeriğinin azalması ile birlikte kalori değerlerinde önemli $(\mathrm{p}<0,05)$ ölçüde bir düşüş yaşanmıştır.

Çizelge 7. Farklı seviyelerde eklenmiş stevya ile şeker içeriğinin azaltılması amaçlanan kek örneklerinin enerji değerleri

\begin{tabular}{|l|c|c|c|c|}
\hline & Kontrol & S1 & S2 & S3 \\
\hline Enerji-Kcal/100 $\mathbf{~ g}^{*}$ & $425^{\mathrm{a}}$ & $400^{\mathrm{b}}$ & $377^{\mathrm{c}}$ & $354^{\mathrm{d}}$ \\
\hline
\end{tabular}

\section{Sonuçlar ve Öneriler}

Kek üretiminde şeker yerine ikame olarak piyasada satılan sıvı stevya kullanılmış olup şekerin ikame edildiği örnekler genel olarak kontrol grubu ile benzer sonuçlara sahip olmuştur. Bu sayede ürün özellikleri üzerinde olumsuz bir etkiye sahip olmadan $100 \mathrm{~g}$ kek tüketimi ile alınacak enerji miktarında yaklaşık \% 6-16’lık bir azalma sağlanabilir. Pişme kaybı ve kek verimi göz önüne alındığında ise \%50 oranında şekerin ikame edildiği örnekler ön plana çıkmaktadır. Günümüzde düşük kalorili gıdalara ilginin katlanarak arttığı düşünüldüğünde stevya kullanılan keklerdeki enerji düşüşünün çok önemli olduğu aşikardır. Gıda sektöründe stevya kullanımı yaygınlaşmalıdır. Optimum kullanım oranları ve depolama süresince meydana gelebilecek değişimler açısından daha ileri araştırmaların gerçekleştirilmesine ihtiyaç vardır.

\section{Kaynaklar}

AACCI, (2000). Methods (10-05.01./10-91.01) Guidelines for measurement of volume by rapeseed displacement. Approved Methods of Analysis, 11th edition. St. Paul, MN: AACCInternational.

Aswin, K.A.,Sankara, N.B.,Sandiya, R., (2015). Stevia the Ideal Sweetener: A Review. Research Journal of Pharmaceutical, Biologicaland Chemical Sciences, 6 (2):174.

Chatsudthipong, V.,Muanprasat, C., (2009). Stevioside and Related Compounds: Therapeutic Benefits Beyond Sweetness. Pharmacol Ther, 121, 41-54.

Dizlek, H., (2003). Farklı kabartma tozlarının değişik oranlarda kullanılmasının ve kek hamurunun pişirme öncesinde bekletilmesinin pandispanya nitelikleri üzerine etkilerinin incelenmesi. Çukurova Üniversitesi Fen Bilimleri Enstitüsü Gıda Mühendisliği Anabilim Dalı, 85 sayfa, Adana.

Dizlek, H., Özer, M.S., Gül, H., (2008). Keklerin Yapısal Özelliklerinin Belirlenmesinde Kullanılan Ölçütler. Türkiye 10. Gida Kongresi. Erzurum.

Dizlek, H., (2013). Kremalı kek (yaş pasta) bileşenleri ve üretimi. Dünya Gıda Dergisi, 18(2013-06):77-84.

Dizlek, H. ve Altan, A., (2013). Pişirme öncesinde hamurun kısa süre bekletilmesinin pandispanya nitelikleri üzerine etkisi. Gida Dergisi, 38(1):31-38.

Dizlek, H. and Altan, A., (2015). Determination of sponge cake volume with a mathematical method. Quality Assurance and Safety of Crops and Foods, 7(4):551-557. (DOI: 10.3920/QAS2014.0463)

Dizlek, H., (2015). Effects of amount of batter in baking cup on muffin quality. International Journal of Food Engineering, 11(5):629-640. (DOI: 10.1515/ijfe-2015-0066) 
Dizlek, H. and Özer, M.S., (2016). The impacts of various ratios of different hydrocolloids and surfactants on quality characteristics of corn starch based gluten-free bread. Cereal Research Communications, 44(2):298-308. (DOI: 10.1556/0806.43.2015.049)

Dizlek, H. and Özer, M.S., (2018). The effects of various ratios of sunflower oil and surfactant on household type cake quality. Journal of Food Measurement and Characterization, 12(1):173-181. (DOI: 10.1007/s11694-017-9628-9)

Gao, J., Brennan, C.S., Mason, S.L., Brennan, M.A., (2016). Effect of sugar replacement with stevianna and inulin on the texture and predictive glycaemic response of muffins. International Journal of Food Science and Technology, 51, 1979-1987.

Giritlioğlu, E.,Dizlek. H., (2018). Sakaroz ikamesi olarak farklı tip ve düzeylerde şeker otu (Stevia rebaudiana Bertoni) bazlı tatlandırıcı kullanılmasının bisküvi nitelikleri üzerine etkileri. Gıda, (2018) 43(1): 21-33 doi: 10.15237/gida.GD17076

Gürleyik, E., (2010). Stevya'nın rat Karaciğerinde Oksidan/Antioksidan Sistem Üzerine Etkisinin Araştırılması. Ankara: Ankara Üniversitesi Tıp Fakültesi, Tıpta Uzmalık Tezi.

Hemada, H.M.,Shehata, A.E.N., Mohamed, E.F., Abd El-magied, S.F., (2016). The impact of Natural Stevia Extract (Stevioside) as a sucrose Replace on Quality Characteristics of Selected Food Products. Middle East Journal of Applied Sciences, 6(1): 40-50

Hojjatoleslami, M., Azizi, M-H. (2015). Impact of Tragacanth and Xanthan Gums on the Physical and Textural Characteristics of Gluten-free Cake. Nutrition and Food Sciennces Research, 2(2):29-37.

İnanç, L.A., Çınar, İ., (2009). Alternatif Doğal Tatlandırıcı : Stevya. Gıda, 34(6), 411-415.

JECFA, (2007). Steviolglycosides Chemical and Technical Assessment (CTA) - Page 1( 7)

Karaca, S., (2010). Stevia Rebaudiana Yapraklarından Ekstrakte Edilen "Stevioside" ile "RebaudiosideA"nın Meyveli ve Gazlı İçeceklerde Kullanımı. Sakarya Üniversitesi Fen Bilimleri Enstitüsü Yüksek Lisans Tezi.

Khalil, S.R.A., Mohamed, E.S., Attia, A.E., (2015). Productivity and Quality of Stevia and The Effects of Drying on Steviosides and Its Usage in Bakery. Journal Food and Dairy Science, MansouraUniversity. 6(10):591-611

Nip, W.K.,(2014). Sweeteners. Bakery Products: Science and Technology (ed:W. Zhou\& Y.H. Hui). Pp. 137160. Oxford: WileyBlackwell. ISBN: 978-1-119-96715-6.

Vatankhah, M.,Garavand, F., Elhamirad, A., Yaghbani, M., (2015). Influence of sugar replacement by stevioside on physicochemical and sensory properties of biscuit. Quality Assurance and Safety of Crops \& Foods, 7 (3): 393-400

Yıldız, Ö., (2002). Düşük kalorili kek üretimi üzerine bir araştırma. Yüksek Lisans Tezi. Yüzüncü Y1l Üniversitesi, Fen Bilimleri Enstitüsü, Gıda Mühendisliği A.B.D. Van.

Zabihollahi, N., (2014). Düşük Kalorili Kek Üretiminde Kavrulmuş Buğdy Unu, Stevya ve Polidekstroz Kullanım İmkanının Araştırılması. Yüksek Lisans Tezi. Atatürk Üniversitesi, Fen Bilimleri Enstitüsü, Gıda Mühendisliği A.B.D. Erzurum. 